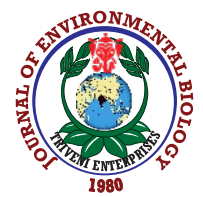

\title{
Effect of culture media, auxins and genotypes on plantlet regeneration from oil palm (Elaeis guineensis Jacq.) zygotic embryos through somatic embryogenesis
}

\author{
D.S. Sparjanbabu', P.N. Kumar', S.R.K. Motukuri ${ }^{1}{ }^{2}$, D. Ramajayam ${ }^{3}$, B. Susanthi ${ }^{4}$ and H.S. Prasanna ${ }^{5}$ \\ 'Koneru Lakshmaiah Education Foundation, Deemed to be University, Vaddeswaram - 522 502, India \\ ${ }^{2}$ ICAR-Directorate of Floricultural Research, Pune - 411 005, India \\ ${ }^{3}$ ICAR-National Research Centre for Banana, Tiruchirapally - 620 102, India \\ ${ }^{4}$ ICAR-Indian Institute of Oil Palm Research, Pedavegi-534 450, India \\ ${ }^{5}$ Department of Horticulture, University of Horticultural Sciences, Bagalkot-587 104, India \\ *Corresponding Author Email : msrkrishna_bt@kluniversity.in
}

\section{Abstract}

Aim: This study evaluated efficient culture media for the regeneration of elite material through somatic embryogenesis from oil palm zygotic embryos.

Methodology: For callus induction, zygotic embryos of four elite genotypes (G1264T, G2-238DX17P, G3-37DX17P and G4-237T) were cultured on three basal media (Y3, MS and N6) with different auxin $2 \mathrm{mg} \mathrm{l}^{-1}$ (Picloram, 2,4-D and Dicamba) combinations. Subculture was made every month for three passages. It evaluated various callus characters. The embryogenic calli from callus induction media were transferred to the embryo maturation medium and subcultured until the polyembryoids formed. For shoot and root formation, somatic embryo clumps were transferred into regeneration media. In-vitro plantlets with well-grown roots were hardened in pots for six weeks and assessed clonal fidelity using polymorphic SSR primers.

Results: Among the treatments, calli from N6+2,4-D, Y3+2,4-D and N6+Picloram showed the highest embryogenic callus potential. G4-237T induced more embryogenic calli (32.982) among genotypes, which was on par with G1-264T (24.196). Embryogenic calli grown on N6 media with Dicamba showed the highest proliferation rate (1.141). After 60 days of culture on regeneration media, the highest number of plantlets per somatic embryogenic clump was obtained from G1264T on N6 media supplemented with Dicamba.

Interpretation: Culture media salt concentration showed a significant difference among media by causing perturbations of auxin flow during somatic embryogenesis affecting callus induction, proliferation and plantlet regeneration. This may be useful for standardizing the genotype-specific regeneration media in oil palm.

Key words: Auxin, Genotype, Oil palm, Somatic embryogenesis, Zygotic embryo
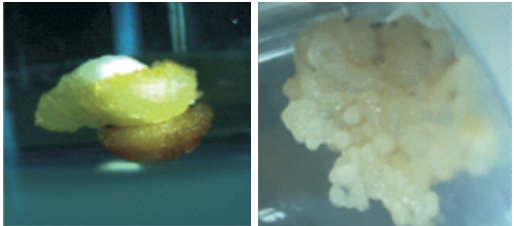

Embryogenic calli in callus induction and proliferation media $\downarrow 3$ months

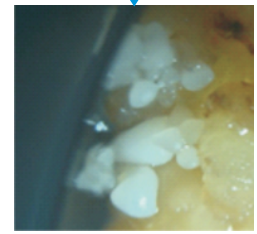

Somatic embryos in embryo maturation media

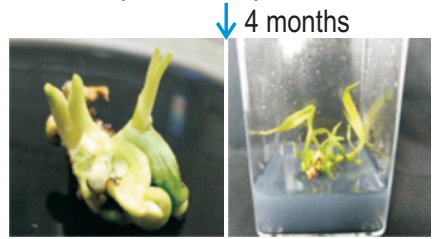

Plantlet regeneration in regeneration media $\downarrow 2$ months

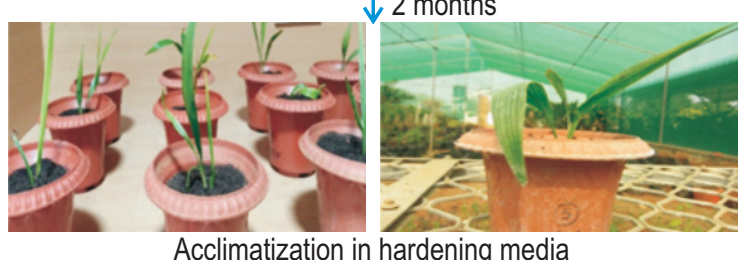

How to cite : Effect of culture media, auxins and genotypes on plantlet regeneration from oil palm (Elaeis guineensis Jacq.) zygotic embryos through somatic embryogenesis. J. Environ. Biol., 42, 1232-1238 (2021). 


\section{Introduction}

Oil palm (Elaeis guineensis Jacq.) is a typical tropical plantation crop with an outstanding oil yield of approximately $6 \mathrm{t}$ $\mathrm{ha}^{-1}$. Being a versatile oil of great value accounts for $36 \%$ of the total vegetable oil production, while kernel oil accounts for $4 \%$ (Sylvie Weckx et al., 2019). Due to the increased demand in the last two decades, oil palm cultivation has expanded enormously. Its further expansion is hampered by elite planting material scarcity due to long germination period (1-3 years) and low germination rate $(30 \%)$ of conventional seed production. Being a monocotyledon with a single growing apex does not produce axillary shoots, making vegetative propagation impossible (Sparjanbabu et al., 2019). Hence, it must be propagated in-vitro by indirect somatic embryogenesis; thus, somatic embryogenesis has become the critical method for multiplicating elite genotypes. Generally, somatic embryogenesis elucidates a complete sculpt of totipotency and comprises a complex signalling network.

Furthermore, reprogramming gene expression patterns regulated in a specific way is a process where somatic cells redifferentiate into totipotent embryonic cells that can further develop into somatic embryos (Guan et al., 2016). Somatic embryogenesis in oil palm using various explants have been reported but not widely implemented because of limited availability of explants, low efficiency and high risk of somaclonal variations. Somatic embryos are characterized based on bipolar structure with specific embryonic organs such as radical, hypocotyls and cotyledons similar to zygotic embryos. Thus, zygotic embryos can respond well in indirect somatic embryogenesis because of their embryogenic destiny. As stated by Balzon et al. (2013), cloning of zygotic embryo can accelerate selection cycles in genetic improvement program, this is especially true in backcross generations where each embryo represents a unique genotype. The ability to reproduce each genotype by cloning allows more effective evaluation through replication in field experiments.

Moreover, for several plant species and oil palm, zygotic embryos are the most enviable source because of their abundant availability (Sparjanbabu et al., 2019; 2020 a, b). However, several factors can induce somatic embryogenesis which includes culture media, type of auxin and genotype of mother plant. The composition of medium is vital to the thriving culture, and several researchers have claimed success in different media (Thuzar et al., 2011; Parveez, 2010; Muniran et al., 2008); however, there is no optimized genotype-specific medium. Similarly, plant growth regulators also play a critical role in morphogenesis and embryogenesis (Suranthran et al., 2011; Thuzar et al., 2011). The intriguing process of somatic embryogenesis is required specific inductive signals from auxins triggering the embryogenic transition from somatic cells. However, auxins' role during the initial phases of somatic embryo development remains elusive (Elhiti and Stasolla., 2011). Balzon et al. (2013) described that "the genotype selection may improve successful establishment of embryogenic potential probability," and several researchers have also described variations in the capacity of several oil palm genotypes to somatic embryogenesis (Balzon et al., 2013; Soh et al., 2011; Konan et al., 2010; Thawaro and Te-chato, 2010). Hence, the present study was conducted to optimize efficient culture media for genotype-specific somatic embryogenesis and plant regeneration.

\section{Materials and Methods}

Fresh fruit bunches of four mature oil palm genotypes $\mathrm{G} 1$ (264T), G2 (238DX17P), G3 (37DX17P) and G4 (237T) were obtained from ICAR-IIOPR, Pedavegi, Andhra Pradesh, India. Fresh fruit bunches of four genotypes were harvested, and fruits were depericarped; the shell was removed by cracking with a hammer to release the kernels. Obtained kernels were surface sterilized by adding few drops of Tween-20 in distilled water for 5 min and then treated with fungicide solution (1\% Carbendazim and $1 \%$ Mancozeb) further soaked in sterile distilled water for 4-5 days for attaining the desired moisture content of zygotic embryo. The kernels were washed several times with Tween-20 solution for $15 \mathrm{~min}$, washed with fungicide solution, immersed in ethanol for 1 min and washed with 20\% sodium hypochlorite solution for $20 \mathrm{~min}$. The kernels were halved, sterilized with $29 \%$ sodium hypochlorite solution for $20 \mathrm{~min}$, and then washed with sterile distilled water three to four times before inoculation.

For callus induction and proliferation, three types of basal culture media viz Y3 (Eeuwens, 1976), MS (Murashige and Skoog, 1962) and N6 (Chu et al., 1975) were supplemented with 2 $\mathrm{mg} \mathrm{l}^{-1}$ of different Auxins: Picloram, 2,4-D and Dicamba. The $\mathrm{pH}$ of the media was adjusted to 5.8 and $8.0 \mathrm{~g} \mathrm{l}^{-1}$ agar was added, prior to sterilization at $121^{\circ} \mathrm{C}$ for $15 \mathrm{~min}$. Each treatment consisted of 90 embryos and was replicated in two series. The cultures were incubated at $27 \pm 2^{\circ} \mathrm{C}$ under dark conditions during the entire process of callus induction and proliferation. Subculture was made every month for three passages and evaluated for callus induction, callus colour, type of callus, size of callus, explant surface covered by callus and embryogenic calli on all explants at the end of third passage. After 90 days of culture, the embryogenic calli from callus induction media were transferred to embryo maturation medium (N6 + 0.1 $\mathrm{mg} \mathrm{l}^{-1} 2,4-\mathrm{D}, 0.16 \mathrm{~g} \mathrm{l}^{-1}$ Putrescine, $0.5 \mathrm{~g} \mathrm{I}^{-1}$ casein amino acids and $2.0 \mathrm{~g} \mathrm{I}^{-1}$ activated charcoal). Subcultures were made every month onto fresh medium for four passages until polyembryoids were differentiated. For shoot and root formation, somatic embryo clumps were transferred into regeneration media (N6 + NAA 0.5 $\mathrm{mgl}^{-1}$, BAP $1.0 \mathrm{mg} \mathrm{l}^{-1}$, activated charcoal $0.5 \mathrm{gl}^{-1}$ ). The number of plantlets with balanced shoots and roots, plant height and number of leaves were recorded after two months of culture. These plantlets were maintained in Magenta boxes containing halfstrength MS medium for two months under $16 \mathrm{hr}$ photoperiod at 
$27 \pm 2{ }^{\circ} \mathrm{C}$. In-vitro plantlets with well grown roots were removed from the boxes and washed thoroughly with sterile distilled water and then planted in plastic pots on a substrate composed of vermiculite, cocopeat and soilrite (1:1:1). The plantlets were hardened in pots for six weeks and subsequently shifted to greenhouse for further acclimatization.

To assess the clonal fidelity, total genomic DNA was extracted from $100 \mathrm{mg}$ of leaf tissue of in-vitro regenerated plantlet by CTAB extraction method. The quality of DNA was checked on $0.8 \%$ agarose gel. stained with ethidium bromide and documented using Alpha Imager Gel Documentation System. Tissue from embryogenic callus and twenty in-vitro raised plantlets were tested for clonal fidelity using a set of 07 polymorphic SSR primers, i.e., SMG00114, SPSC00072, $\mathrm{mEgCIR0322,} \mathrm{mEgCR2628,} \mathrm{mEgCIR22241,} \mathrm{mEgCIR3400} \mathrm{and}$ mEgCIR3732 (Table 3). All SSR primers were synthesized from Bioserve (India) and initially screened for polymorphism and reproducibility. Gels were visualized in a gel documentation system (Bio-Rad).

Statistical analysis was carried out using ICAR-WASP 2.0 software. Data were subjected to ANOVA and means were compared by F-test at $5 \%$ probability.

\section{Results and Discussion}

In the present study, the process of somatic embryogenesis involved three vital developmental stages: callus induction, callus proliferation and somatic embryo maturation, and plant regeneration. During callus induction, it was observed that all the zygotic embryos started swelling after one week of culture, irrespective of media, auxin and genotype whereas after nine weeks of culture, variations in the colour and texture of callus mass observed may be due to rupture and opening of proximal region of zygotic embryo, which enabled exposure of meristematic masses and formation of primary calli. Three type of calluses were observed viz compact, nodular and friable with three colours, i.e., yellow, white and translucent. Mostly, the compact calluses were muddy white and translucent. The nodular and friable callus were yellow in colour. Among the media, N6 media induced the highest yellow coloured calli (63.380) and lowest white and translucent calli, which was on par with MS media; whereas Y3 media induced the lowest yellow coloured and the highest white coloured calli (Table 1).

Among the auxins, Picloram induced more yellow calli (53.938), which is on par with Dicamba (53.105) while 2,4-D induced the lowest yellow calli (39.957). In contrast, more translucent calli were induced by 2,4-D (13.264), which was on par with Picloram (8.868). Similar results were observed by Pàdua et al. (2017) on calli from the oil palm inflorescence. Dicamba, on the other hand, induced the lowest translucent calli (13.889), no significant impact of auxins was induced on white coloured calli (Table 1). Genotypes had shown a significant effect on the callus colour (Table 1). Among the genotypes, G1-264T induced more number of yellow coloured calli (66.582), G3-37D $\mathrm{X} 17 \mathrm{P}$ induced the least number of yellow coloured calli (29.629), G4-237T has induced more white colour calli (44.016) and G2238D X 17P caused more number of translucent calli (13.880). Pàdua et al. $(2013,2017)$ reported that translucent colour calli cells composed of vacuolated cells with broken cell walls and cell organelles may be due to apoptotic process. Here, large vacuoles may play a vital role in programmed cell death (Lam et al., 2000). Elhiti and Stasolla (2011) also reported that auxin transport inhibitors causing an increased number of differentiated cells with

Table 1: Effect of media, auxins and genotypes on the relative proportion (percentage) colour of the callus derived from oil palm zygotic embryos.

\begin{tabular}{|c|c|c|c|c|c|c|}
\hline \multirow[b]{3}{*}{ Media (M) } & \multirow[b]{3}{*}{ Auxins (A) } & \multirow[b]{3}{*}{ Genotype (G) } & \multicolumn{4}{|l|}{ Treatments } \\
\hline & & & & \multicolumn{3}{|c|}{ Callus colour } \\
\hline & & & & Yellow & White & Translucent \\
\hline Y3 & & & M1 & 29.196 & 42.993 & 15.311 \\
\hline MS & & & M2 & 54.423 & 26.048 & 2.862 \\
\hline \multirow[t]{12}{*}{ N6 } & & & M3 & 63.380 & 13.721 & 7.899 \\
\hline & Picloram & & $\mathrm{A} 1$ & 53.938 & 28.861 & 8.868 \\
\hline & 2,4-D & & $\mathrm{A} 2$ & 39.957 & 25.946 & 13.264 \\
\hline & Dicamba & & A3 & 53.105 & 27.955 & 3.940 \\
\hline & & $264 \mathrm{~T}$ & $\mathrm{G} 1$ & 66.582 & 25.778 & 7.640 \\
\hline & & $238 \mathrm{D} \times 17 \mathrm{P}$ & $\mathrm{G} 2$ & 57.037 & 31.296 & 13.880 \\
\hline & & 37DX17P & G3 & 29.629 & 9.259 & 0.000 \\
\hline & & $237 \mathrm{~T}$ & G4 & 42.750 & 44.016 & 13.234 \\
\hline & & & CV $(\%)$ & 31.743 & 64.912 & 109.611 \\
\hline & & & CD at5\% (M) & 9.115 & 10.494 & 5.582 \\
\hline & & & $\mathrm{CD}$ at $5 \%(\mathrm{~A})$ & 9.115 & 10.494 & 5.582 \\
\hline & & & $\mathrm{CD}$ at $5 \%(\mathrm{G})$ & 10.525 & 12.117 & 6.446 \\
\hline
\end{tabular}




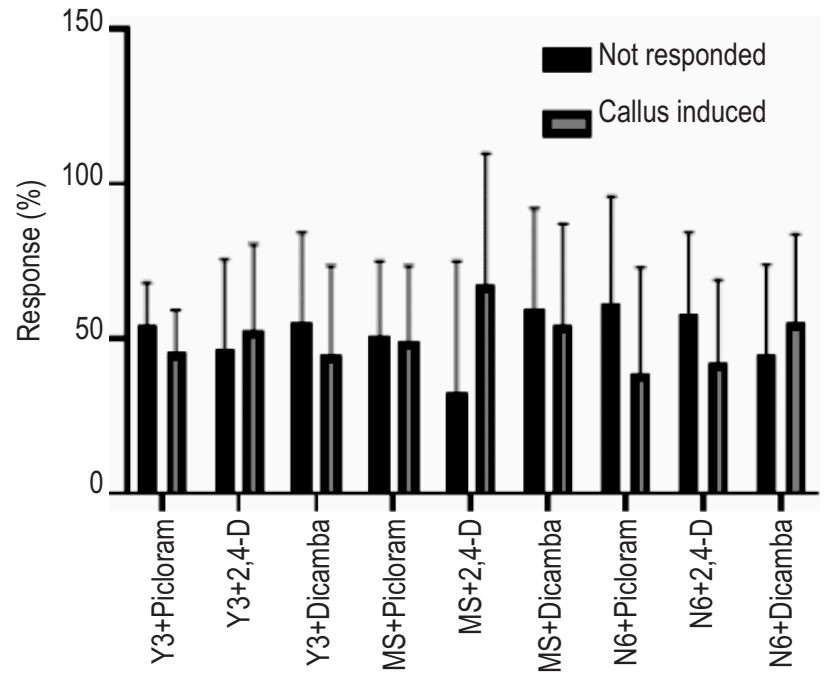

Fig. 1 : Effect of media and auxin combination on callus induction from oil palm zygotic embryo; Values are mean \pm SE.

larger vacuoles. Earlier researchers have reported the effect of callus colour on embryogenesis, Padua et al. (2017) observed isodiametrically arranged yellow coloured calli cells with cell organelles. It has been proved that in oil palm, calli induced in zygotic embryos with cell organelles are characterized as meristematic and they subsequently regenerate into plants (de Silva et al., 2014; Bar and Dawayat, 2014).

Type of media, auxin and genotype showed a significant effect on callus induction (Fig. 1). Among the media, MS media induced the highest percentage of primary callus (52.388) followed by Y 3 media (47.54) and N6 media (45.269). The results obtained were contrary to the reports of Thuzar et al. (2011) and Abdullah et al. (2005), where the highest callus induction rate was achieved in $\mathrm{N} 6$ media. Whereas among auxins. similar to Balzon et. al. (2013) and Thuzar et.al. (2011, 2012) 2,4-D has shown highest callus induction rate (53.998) followed by Dicamba (46.805) and Picloram (44.395). These results are in agreement with the studies of Balzon et al. (2013) and Thuzar et al. (2011, 2012) who deconstrated that 2,4-D produced the highest callus induction rate (53.998), followed by Dicamba (46.805) and Picloram (44.395). Among the genotypes, G4-237T showed the highest callus induction rate (65.798), which was on par with G1264T (65.743), followed by G2-238D X 17P (53.385). The lowest callus induction was observed in G3-37D X 17P (8.671).

After three passages in the same culture media, the primary calli evolved into compressed embryogenic calli, nodular and friable, and yellow. Whereas non-embryogenic calli grew as a compact and nodular appearance with white and translucent colouration, a significant interaction was found between media and auxins in this phase. Among the treatments, calli from N6 media with 2,4-D had showed the highest embryogenic callus potential (35.00), which was on par with the calli from Y3 media with 2,4-D (34.375) and N6 media with Picloram (29.911). Similar results were observed by several earlier studies (Balzon et al., 2013; Thuzar et al., 2011; Jayanthi et al., 2011; Thawaro and Techato, 2009; Abdullah et al., 2005). Use of exogenous 2,4-D create a double effect of endogenous Indole-3-acetic acid by inducing the nodular structures from epidermal cells of mature zygotic embryo and even by acting as a stress factor (Feher et al., 2003). In contrast, calli from MS media with all three auxins had shown the least embryogenic potential, which may be due to the inhibition of auxin flow in the callus (Elhiti and Stasolla, 2011). Among genotypes (Fig. 2a) G4-237T has induced more embryogenic calli (32.982), which were on par with G1-264T (24.196) followed by G2-238D X 17P (15.625) whereas G3-37D X $17 \mathrm{P}$ had not induced any embryogenic calli.

During callus proliferation and somatic embryo maturation, the embryogenic calli further transferred to proliferation and embryo maturation media ( $\mathrm{N} 6+0.1 \mathrm{mg} \mathrm{I}^{-1} 2,4-\mathrm{D}$, $0.16 \mathrm{~g} \mathrm{l}^{-1}$ Putrescine, $0.5 \mathrm{~g} \mathrm{l}^{-1}$ casein amino acids and $2.0 \mathrm{~g} \mathrm{l}^{-1}$ activated charcoal) where embryogenic callus further proliferated by repetitive cycles of cellular division. And among the treatments, calli grown on $N 6$ media with Dicamba had shown the highest proliferation rate (1.141), which may be due to induction of nodular structures from both epidermis and vascular tissues of zygotic embryo. Similar findings were reported in oil palm zygotic embryo, young leaf by Te-chato (1998) and Batista et al. (2018) in
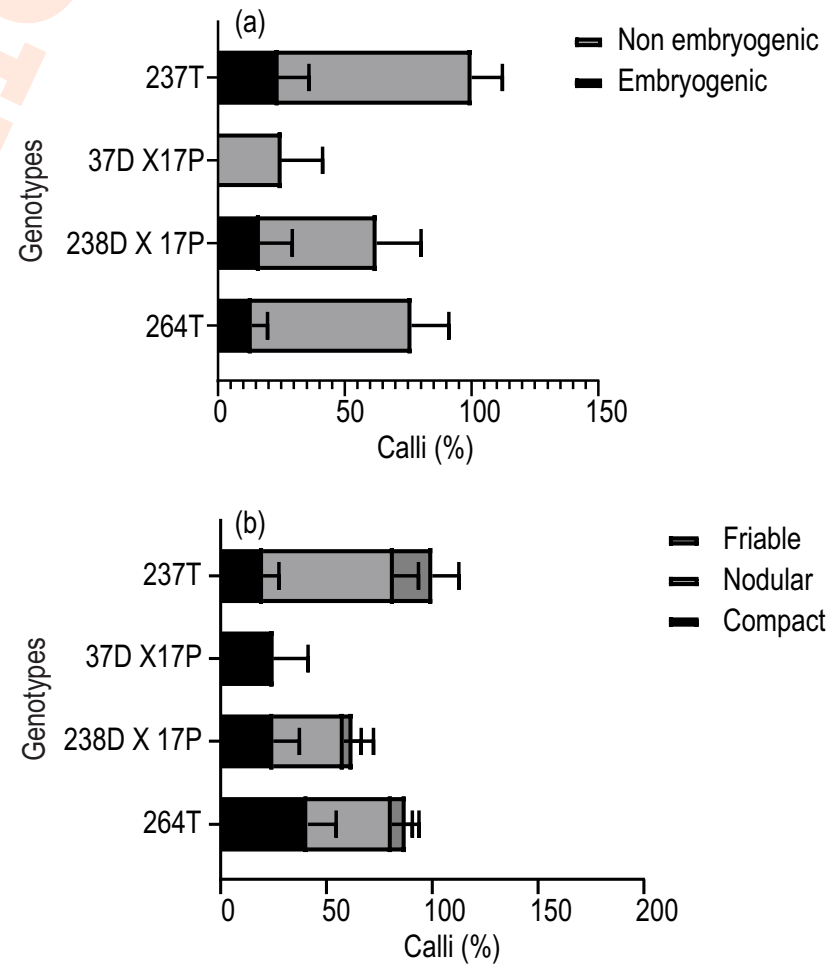

Fig. 2 : Differential response of oil palm genotypes on (a) production of embryogenic calli and (b) on type of callus. Values are mean \pm S.E. 
Table 2 : Effect of auxins on acclimatization of in-vitro regenerated plantlets of oil palm.

\begin{tabular}{llll}
\hline Treatment & Height & No of leaves & \\
\hline N6+Dicamba+264T & 6.143 & 2.714 & A \\
N6+2,4-D+264T & 0.500 & 1.000 & $B$ \\
N6+Picloram+264T & 0.750 & 1.000 & $B$ \\
CV & 44.399 & 31.310 & \\
CD at $(5 \%)$ & 4.235 & 1.510 & \\
\hline
\end{tabular}

Table 3 : Primers used for the evaluation of clonal fidelity

\begin{tabular}{lll}
\hline Primer name & Sequence Forward $\left(\mathbf{5}^{\prime} \mathbf{3}\right)$ & Sequence Reverse $\left(\mathbf{5}^{\prime} \mathbf{- 3}\right)$ \\
\hline SMG00114 & CCTGGTTCATCTCCCTTCAAA & CCCTTTCCTCTTGGTTACG \\
SPSC00072 & GTGCTATCCTCATCGAGCAA & CATCACATGCTGCGATCTCT \\
mEgCIR0332 & ATTTCGTAAGGTGGGTGT & CCTCCAAACTCCTCTGT \\
mEgCIR2628 & TCGTGGTGGGTGCATTC & GGGTGGACTTGGATCGTACT \\
mEgCIR2224 & TGGGGATGGGGAGCAG & TCGCACCGCCTCCTACC \\
mEgCIR3400 & CAATTCCAGCGTCACTATAG & AGTGGCAGTGGAAAACAGT \\
mEgCIR3732 & ATTTTATTTGGCTTGGTATA & ACTTTTCTATCTAATTCTTGAAGAT \\
\hline
\end{tabular}

Eucalyptus crop, whereas N6 media with Picloram (1.100) also showed on par results with Dicamba, similar findings were reported in Picloram by Balzon et al. (2013); Thuzar et al. (2011) and Te-chato and Hilae (2007). After 90 days of proliferation, embryogenic calli with nodular aspects were started, developing into friable white calli that were weakly connected to the remaining embryogenic nodular calli. The highest friable and nodular calli was induced by G4-237T, followed by G1-264T and G2-238D X 17P and the highest compact calli was produced by G3-37D X 17P (Fig. 2b). The passing of embryogenic calli to this stage made it possible to observe somatic embryo differentiation and maturation. The whitish embryogenic calli were developed into globular and torpedo shapes, thereafter, differentiated into cotyledonary stage polyembryoids. The embryo maturation medium containing Putrescine and $\mathrm{AC}$ aids the formation of somatic embryo from polyembryoids.

For plantlet regeneration, somatic embryo clumps were transferred into plant regeneration media (N6+NAA $0.5 \mathrm{mg} \mathrm{l}^{-1}$, BAP $1 \mathrm{mg} \mathrm{l}^{-1}$, Activated Charcoal $0.5 \mathrm{~g} \mathrm{l}^{-1}$ ). After two months of culture, the highest number of plantlets per somatic embryogenic clump was obtained in genotype 264T on N6 media supplemented with Dicamba, followed by N6 with Picloram and N6 with 2,4-D. Here, the composition of media had played a vital role, where $\mathrm{N} 6$ media had low levels of nitrogen, amino acids and other micronutrients, particularly boron and manganese, than the remaining two media MS and Y3. In general, oil palm somatic embryogenesis and plantlet regeneration process take 16-24 months on average (Abdullah et al., 2005) whereas the present protocol had achieved it in 9 months, which was similar to the report Thuzar et al. (2011), but contrary to Thuzar et al. (2011) and Konan et al. (2007), this may be due to culture medium influence on carbon- nitrogen relationship in rooting (Assis and Teixeira,
1998). Moreover, moderate nitrogen deficiency is usually more beneficial to rooting than excessive or even adequate levels. According to Ribeiro et al. (2011), the higher concentration of salts in MS medium inhibited root growth in plantlets; similar results also observed by Ferreira et al. (2002) in Theobroma gradiflorum where high nutrient availability prevented plantlet rooting. Thus, this protocol may reduce the somaclonal variations and clonal fidelity problems associated with prolonged culture (Eeuwens et al., 2002; Besse et al.,1992) and more than $80 \%$ of plantlets with well grown roots were acclimatized for six weeks in substrate consisting vermiculite, cocopeat and soilrite (1:1:1) as mentioned by Sparjanbabu et al. (2020) Further, the plantlets regenerated from G1-264T cultured on N6 media supplemented with Dicamba showed more plantlet height (6.143) and number of leaves (2.714) than other treatments (Table 2).

Micropropagation is prone to somaclonal variation and does not maintain genetic fidelity of regenerated plantlets, thus to evaluate clonal fidelity, the fingerprinting profiles of twenty in-vitro regenerated and one embryogenic donor callus was generated using a total of seven polymorphic pre-screened polymorphic simple sequence repeat (SSR) markers (Table 3) (Billote et al., 2005). The results showed that out of total 160 bands scored, 157 bands produced were monomorphic (98.125\%), and three bands were polymorphic $(1.875 \%)$. Thus, the present study confirms that somatic embryogenesis through callus induction is the safest mode of in-vitro regeneration to produce true-to-type plantlets in oil palm, and the observation of low-level polymorphism showed that these seven SSR markers could be used to test the genetic relationship of regenerated plantlets with their callus tissue and to check uniformity of clonal plantlets.

In conclusion, an efficient plant regeneration protocol was developed through somatic embryogenesis using mature zygotic 
embryos within nine months of shortened culture time by excluding the separate root induction phase. In this present investigation, N6 media was the most responsive and efficient medium, and Dicamba was highly effective in somatic embryogenesis and plant regeneration. Whereas among genotypes, as G1-264T had the highest potential of in-vitro regeneration, the selection of such genotypes would provide an increased probability in the successful establishment of embryogenic protocols for germplasm conservation and breeding programs.

\section{Add-on Information}

Author's contribution: D. S. Sparjanbabu: Executed the experiment, collected the data, analyzed the data and wrote the draft of manuscript; P. N. Kumar: Concept and design of the investigation and supervision; S.R.K Motukuri: Interpreted the data, revision of the manuscript; D. Ramajayam: Concept and design of the investigation and analyzed the data; B. Susanthi: Executed the experiment and collected the data; H. S. Prasanna: Collected the data.

Research content : The research content of manuscript is original and has not been published elsewhere.

Ethical approval : NotApplicable

Conflict of interest: The authors declare that there is no conflict of interest.

Data from other sources : NotApplicable

Consent to publish: All authors agree to publish the paper in Journal of Environmental Biology.

\section{Acknowledgments}

The authors thank the National Mission on Oilseeds and Oil Palm (NMOOP), DAC, Ministry of Agriculture and Farmer Welfare, Govt. of India for the financial support and fellowship. Special thanks to Dr. S. Arulraj and Dr. R. K. Mathur for providing laboratory facilities and guidance.

\section{References}

Abdullah, R., A. Zainal, W.Y. Heng, L.C. Li, Y.C. Beng, L.M. Phing, S.A. Sirajuddin, W.Y.S. Ping, J.L. Joseph, S.A. Jusoh, M.R. Muad and Y.L. Huey: Immature embryo: A useful tool for oil palm (Elaeis guineensis Jacq.) genetic transformation studies. Elect. J. Biotechnol., 8, 0717-3458 (2005).

Assis, T.F. de and S.L. Teixeira: Enraizamento de plantas lenhosas. In: Torres, AC; Caldas LS, Buso, JA. Cultura de tecidos e transformacão genética de plantas. Brasília: EmbrapaSPI/Embrapa-CNPH., pp. 261-296 (1998).

Balzon, T.A., Z.G. Luis and J.E. Scherwinski-Pereira: New approaches to improve the efficiency of somatic embryogenesis in oil palm (Elaeis guineensis Jacq.) from mature zygotic embryos. In Vitro
Cell. Dev. Bio-Plant., 49, 41-50 (2013).

Bar, O.A.E. and M.M.E. Dawayat: Histological changes on regeneration in vitro culture of date palm (Phoenix dactylifera) leaf explants. Aust. J. Crop. Sci., 8, 848-855 (2014).

Batista, T.R., E.G. Mendonça, M.S. Pádua, V.C. Stein and L. Paira: Morpho and cytological differentiation of calli of Eucalyptus grandis $\mathrm{X}$ Eucalyptus urophylla during somatic embryogenesis. Brazil. Archi. Bio. Tech., 61, e18170043 (2018).

Besse, I., J.L. Verdeil, Y. Duval, B. Sotta, R. Maldiney and E. Miginia: Oil palm (Elaeis guineensis Jacq.) clonal fidelity: Endogenous cytokinins and indolacetic acid in embryogenic callus cultures. J. Exp. Bot., 43, 983-989 (1992).

Billotte, N., N. Marseillac, A.M. Risterucci, B. Adon, P. Brottier, F.C. Baurens, R. Singh, A. Herran, H. Asmady, C. Billot, P. Amblard, T.D. Gasselin, B. Courtois, D. Asmono, S.C. Cheah, W. Rohde, E. Ritter and A. Charrier: Microsatellite-based high density linkage map in oil palm (Elaeis guineensis Jacq.). Theor. Appl. Genet., 110, 754-765(2005).

Chu, C.C., C.C. Wang, C.S. Sun, C. Hsu, K.C. Yin, C.Y. Chu and F.Y. Bi: Establishment of an efficient medium for anther culture of rice through comparative experiments on the nitrogen sources. Scientia. Sinica, 18, 659-668 (1975).

de Silva, R.C., Z.G. Luis and E.S. Pereira: The histodifferentiation events involved during the acquisition and development of somatic embryogenesis in oil palm (Elaeis guineensis Jacq.). Plant. Gro. Regul., 72, 67-80a (2014).

Eeuwens, C.J.: Effects of organic nutrients and hormones on growth and development of tissue explants from coconut (Cocos nucifera) and date (Phoenyx dactylifera) palms cultured. In vitro Phys. Plantarum., 42,173-178 (1976).

Eeuwens, C.J., S. Lord, C.R. Donough, V. Rao, G. Valljo and S. Nelson: Effect of tissue culture conditions during embryoid multiplication on the incidence of "mantled" flowering in clonally propagated oil palm. Plant. Cell. Tiss. Org. Cult., 70, 311-323 (2002).

Elhiti, M. and C. Stasolla: Ectopic expression of the Brassica shoot meristem less attenuates the deleterious effects of the auxin transport inhibitor TIBA on somatic embryo number and morphology. Plant Sci., 180, 383-390 (2011).

Feher, A., T.P. Pasternak and D. Dudits: Transition of somatic plant cells to an embryogenic state. Plant. Cell. Tiss. Org. Cul., 74, 201-228 (2003).

Ferreira, M.G.R., F.E.N. Càrdenas, C.H.S. Carvalho, A.A. Carneiro and C.F. Damião Filho: Resposta de eixos embrionários de cupuaçu (Theobroma grandifloram Schum) à concentração de sais, doses de sacarose e renovação do meio de cultivo. Revista Cientifica Symposium, Lavras., 24, pp. 246-248 (2002).

Guan, Y., S.G. Li, X.F. Fan and Z.H. Su: Induction of somatic embryogenesis in woody plants. Front. Plant. Sci., 7, 398 (2016).

Jayanthi, M., N.M. Mohan and P.K. Mandal: Direct somatic embryogenesis and plantlet regeneration in oil palm. J. Plant. Biochem. Biotechnol., 20, 249-251 (2011).

Konan, E.K., T.D. Gasselin, J.Y. Kouadio, A.C. Niamkè, D. Dumet, Y. Duval, A. Rival and F. Engelmann: Field development of oil palms (Elaeis guineensis Jacq.) originating from cryopreserved stabilized polyembryonic cultures. Cryo. Letters, 28, 377-86 (2007).

Konan, E.K., T.D. Gasselin, J.Y. Kouadio, A. Flori, A. Riva, Y. Duval and C. Pannetier: In-vitro conservation of oil palm somatic embryo for 20 years on a hormone-free culture medium: Characteristics of the 
embryogenic cultures, derived plantlets and adult palms. Plant Cell. Rep., 29,1-13 (2010).

Lam, E., H. Fukuda and J. Greenberg: Programmed cell death of tracheary elements as a paradigm in plants. Plant. Mol. Biol., 44, 245-253 (2000).

Muniran, F., J.B. Subhash and H.S. Farida: Micropropagation of Elaeis guineensis Jacq. 'Dura': Comparison of three basal media for efficient regeneration. Indian. J. Exp. Biol., 46, 79-82 (2008).

Murashige, T. and F. Skoog: A revised medium for rapid growth and bioassays with tobacco tissue cultures. Physiologia Plantarum., 15, 473-497 (1962).

Pádua, M.S., L.V. Paiva, C.R.G. Labory, E. Alves, L.C. Silva and V.C. Stein: Induction and characterization of oil palm (Elaeis guineensis Jacq.) proembryogenic masses. AnAcad. Bras. de Ciênc., 85, 1545-1556 (2013).

Pádua, M.S., R.S. Santos, C.R.G. Labory, V.C. Stein and E.G. Mendonça: Histodifferentiation of oil palm somatic embryo development at low auxin concentration. Protoplasma., 255, 1-11 (2017).

Parveez, K.A., A. Othman, U.S. Ramil, R. Sambanthamurthi, M.Y.A. Hasami, A.T. Hashim, A.K. Din, M.B. Wahid, C.T. In Hou and J.F. Shaw: Biocatalysis and Biomolecular Engineering. $5^{\text {th }}$ Edn., Jhon Wiley and Sons, Inc.,New Jersey, pp. 67-81 (2010).

Ribeiro, L.M., S. da C. Neves, P.O. Silva and I.G. Andrade: Germinaçã de embriões zigóticas e desenvolvimento in-vitro de coqvinho-azedo. Rev. Ceres., 58, 133-139 (2011).

Soh, A.C., G. Wong, C.C. Tan, O.S. Chew, S. Chong, Y.W. Ho, C.K. Wong, C.N. Choo, H. Nor Azura and K. Kumar: Commercial-scale propagation and planting of elite oil palm clones: Research and development towards realization. J. Oil. Palm. Res., 23, 935-952 (2011).

Sparjanbabu, D.S., P.N. Kumar, M.S.R. Krishna, D. Ramajayam, B.K. Babu and B. Susanthi: Effect of culture media, plant growth regulators and genotypes on growth and developmental stages of oil palm (Elaeis guineensis Jacq.) zygotic embryos. India. J. Agric. Res., 53,143-150 (2019).

Sparjanbabu, D.S., H.S. Prasanna, D. Ramajayam, P.N. Kumar, M.S.R.
Krishna and B. Susanthi: Data on germination, growth and morphological changes of oil palm (Elaeis guineensis Jacq.) zygotic embryos during in-vitro culturing. Data in Brief, 28,104975 (2020a).

Sparjanbabu, D.S., P.N. Kumar, M.S.R. Krishna, D. Ramajayam, B. Susanthi and H.S. Prasanna: Optimizing the acclimatization process of oil palm (Elaeis guineensis Jacq.) in-vitro plantlets derived from the mature zygotic embryos. Plant. Cell. Biotech. Mol. Bio., 21, 128-134 (2020b).

Suranthran, P., U.R. Sinniah, S. Subramaniam, M.A. Aziz, N. Romzi and S. Gantait: Effect of plant growth regulators and activated charcoal on in-vitro growth and development of oil palm (Elaeis guineensis Jacq. var. Dura) zygotic embryo. African. J. Biotechnol., 10,1060010606 (2011).

Sylvie, W., L. Dirk and M. Ludo: Tissue culture of oil palm: Finding the balance between mass propagation and somaclonal variation. Front. Plant. Sci., 10, 722 (2019).

Te-chato, S.: Callus induction from cultured zygotic embryo of oil palm subsequent to plantlet regeneration. Songkla. J. Sci. Technol., 20, 1-6(1998).

Te-chato, S. and A. Hilae: High-frequency plant regeneration through secondary somatic embryogenesis in oil palm (Elaeis guineensis Jacq. var.tenera). J. Agric. Technol., 3, 345-357 (2007).

Thawaro, S. and S. Te-chato: Effect of genotypes and auxins on callus formation from mature zygotic embryos of hybrid oil palm. J. Agri. Technol., 5, 167-177 (2009).

Thawaro, S. and S. Te-chato: Effect of culture medium and genotype on germination of hybrid oil palm zygotic embryos. Science Asia, 36, 26-32 (2010).

Thuzar, M., A. Vanavichit, S. Tragoonrung and C. Jantasuriyarat: Efficient and rapid plant regeneration of oil palm zygotic embryos cv. 'Tenera' through somatic embryogenesis. Acta Physiologia Plantarum., 33, 123-128 (2011).

Thuzar, M., A. Vanavichit, S. Tragoonrung and C. Jantasuriyarat: Recloning of regenerated plantlets from elite oil palm (Elaeis guineensis Jacq.) cv Tenera. African. J. Biotechnol., 11, 1476114770 (2012). 